\title{
Caring citizens: Emotional engagement and social action in educational settings in New
}

\section{Zealand}

Bronwyn E. Wood, Victoria University of Wellington, New Zealand Bronwyn.wood@vuw.ac.nz

Rowena M. Taylor, Massey University, Palmerston North, New Zealand

R.M.Taylor@massey.ac.nz

Wood, B. E., \& Taylor, R. (2017). Caring citizens: Emotional engagement and social action in educational settings in New Zealand. In J. Horton \& M. Pyer (Eds.), Children, young people and care (pp. 78-92). Oxon/NY: Routledge.

\begin{abstract}
Requirements for more 'active' forms of citizenship participation from children and young people within schooling often rest on unstated emotions of care or empathy. Drawing on research in five New Zealand secondary schools, the chapter examines the interplay of care and young people's social actions within an active citizenship education programme. The paper reports on how teachers established 'caring' classrooms and how their students responded - those who 'cared', and those who didn't care (as much). Analysing these responses through three theoretical approaches to emotion in educational research (Zembylas, 2007) revealed the significance of young people's emotional engagement in their acts of citizenship. It also illustrated the fluidity and pervasiveness of emotions of care when implementing active citizenship education policy and the dynamic ways emotions were constituted within socio-spatial contexts such as classrooms.
\end{abstract}

Bronwyn Wood is a senior lecturer at the Faculty of Education in Victoria University of Wellington, New Zealand. Her research interests lie at the intersection of sociology, geography and education and centre on issues relating to youth participation, citizenship and education.

Rowena Taylor maintains a part-time role at Massey University's Institute of Education, Palmerston North, New Zealand, where she was formerly a senior lecturer. Her research interests are in social studies curriculum and disciplinary literacy in the social sciences, especially geography. 


\section{Introduction}

The use of educational spaces to regulate the young in the ways of modern citizenry is not new. Schools can be thought of as an aggregation of the values, aspirations, and ideals held by social and political agents in society, who employ a range of strategies to attempt to mould young citizens in certain ways (Staeheli 2011). Citizenship education programmes are key to such endeavours as they provide a strategic site for the creation of dispositions and characteristics which will engender responsible, 'good' citizens in the future. In recent years, a growing number of countries have developed and extended their focus on citizenship education (Brooks \& Holford 2009; Kennelly \& Llewellyn 2011; Nelson \& Kerr 2006; Schulz, Ainley, Fraillon, Kerr, \& Losito 2010). Whilst the reasons for this heightened focus on citizenship education are complex, Nelson and Kerr (2006) suggest that new social, economic and environmental challenges and declining rates of youth civic participation have contributed to this. Increasingly, these citizenship education programmes require more 'active' expressions of citizenship where young people not only need to know about civic processes, but also to participate as active citizens (Ross, 2012). This has led to a many new policy initiatives that encourage young people to participate in acts of citizenship - such as through service learning, community participation, social action and volunteering - in many countries including the UK, the US, Canada, Australia and New Zealand (Birdwell, Birnie, \& Mehan, 2013; Davies et al., 2012; Farahmandpour, 2011; Jerome, 2012; Wood \& Black, 2014).

However, while more active forms citizenship education have been adopted across many countries, very little attention has been given how young people actually feel about undertaking citizenship acts as part of their compulsory curriculum. Emotions such as empathy, compassion, concern or anger are likely to underpin the desire or inspiration to 
perform citizenship acts (Jasper 1998), yet, within the context of citizenship education, little mention is made of these emotions and how integral they are to citizenship action especially within formal curricula policy. Instead, citizenship education curricula often appeal to a distant, abstract sense of loyalty to a nation founded upon notions of 'belonging to community' (Wood 2013) or 'responsibilities' and 'duties' as citizens of a democracy (Kennelly \& Llewellyn 2011). Moreover, no guidance is given about what teachers or students are to do in the absence of a sense of care or commitment about the required acts of citizenship or if young people do not feel like performing these acts. Furthermore, taking social action also relies on a sense of agency which leads citizens to act on behalf of others (Osler \& Starkey 2005). This is also closely linked to emotions such as confidence and qualities such as persistence. Yet, there is strong evidence that young people frequently feel disempowered in society as a result of marginalising practices and discriminating processes in society (Kennelly \& Dillabough, 2008) - an aspect citizenship education policy rarely takes into account. This then raises a number of questions in this context: What happens when young people are 'required' to care about an issue in order to take citizenship action as part of curricula or assessment? What if they don't care? Or if they don't feel empowered to act? Does this make them 'bad' citizens? And, how do teachers navigate these requirements?

This chapter examines the interplay of care and young people's social actions within an active citizenship education programme in New Zealand schools. While others have previously proposed that 'caring' is required to make the world a better place (Massey 2004), or that caring itself can be a political act (Bartos 2012), the intersection between emotions of caring and acts of citizenship in schooling has not been well explored. Furthermore, when research has connected emotional engagement with civic action, it has tended to come from psychologically-derived research that fails to account for the nuances of place, temporality 
and human relationships. If we understand that emotions are relational, and that they arise and flow between people (Bondi, 2005), we need to examine how caring occurs within the intergenerational relationships and socio-spatial interactions represented within active citizenship education contexts. In doing so, this research also contributes to wider discussions about the role and nature of emotions in societal interactions and in social activism (Brown \& Pickerill 2009), the significance of empathy in citizenship and social justice endeavours, and the implications of this on the type of citizen evoked within curriculum and educational policy (Pykett, Saward, \& Schaefer 2010).

The context for this research is New Zealand, where, since 2011, students who study Social Studies in the final three years of secondary schooling (Years 11-13, ages 15-18) are assessed for undertaking 'personal social action'. This national assessment initiative forms part of New Zealand's credentialing system, contributing to the National Certificate of Educational Achievement (NCEA) (NZQA 2013). Social Studies has traditionally been the primary vehicle for citizenship education in New Zealand (Archer \& Openshaw 1992) and now includes this social action component at senior levels for both curriculum and assessment purposes. This chapter draws from a two year research project (2015-2016) examining the experiences of teachers and students from five New Zealand secondary schools who were undertaking these social action achievement standards. While curriculum and assessment documents do not include reference to the affective dimensions of taking personal social action, it became evident very early on in our project that for students to take action, they needed a sense of emotional engagement or connection with the selected social issue. In short, they needed to 'care'. Hence, in this chapter, we examine the affective dimension of social action from both the teachers' and students' perspectives, to explore the significance and nature of 'care' in an active citizenship process. 
The chapter begins by providing a conceptual overview for understanding emotions drawing upon Zemblyas' (2007) tri-fold conceptualisation of theoretical approaches to emotion in educational contexts. The aim of this analysis through Zembylas is to consider how theoretical approaches to emotion shape our understandings of emotion in active citizenship. Drawing on empirical data from our research project, we examine how teachers fostered the conditions for 'caring' and 'care-full' classrooms, through their own affective responses to social issues and pedagogical strategies, and their students' responses. Two groups of students are examined - those who 'cared' and those who didn't care (as much). We discuss the implications of these affective positions, and examine how emotions such as caring interact with acts of citizenship. We conclude by considering the implications of these findings, arguing that meaningful social action needs to be centred on an authentic cognitive and emotional connection to social issues, and that teachers need to be aware of their role in nurturing this affective engagement if they are encourage the development of active and empowered citizens.

\section{Caring classrooms: How do we understand care in educational contexts?}

Care is inseparable from educational contexts. Children and young people in educational institutions have always been 'cared for'. Much less attention, however, has historically been paid to exploring how young people themselves are carers, or how classrooms are 'sites of

caring'. One reason why emotions in classrooms are often an 'absent-presence' (Boler 1999, $\mathrm{xv}$ ), is the long-standing priority given in education to cognitive pedagogies which are reasoned, logical and as 'uncontaminated' by emotion as possible (Kenway \& Youdell 2011). Thus emotions are often relegated to a backseat in favour of truth, rationality and reason, or are simply unseen (Sheppard, Katz, and Grosland 2015). 
A recent growing body of work addresses this imbalance. In education, Boler's (1999) seminal work in Feeling Power: Emotion and education, and Zembylas' exploration of the politics of emotion in classrooms (Zembylas 2005, Zembylas et al. 2011, 2014) have helped to advance thinking in this area. Alongside this, a growing literature that specifically addresses the emotional geographies of education has highlighted the inseparable nature of emotions from the social, cultural, economic and political landscapes of education (Ahmed 2014, Bartos 2012, Gagen 2015, Kenway \&Youdell 2011, Black 2015, Nairn \& Higgins 2011, Wood 2013). These studies of emotions have helped to interrogate the 'embodied, material and particularized experience of our daily lives' (Boler 1999, p.7) in educational contexts and draw our attention to the deep connections between emotions, people and places (Bondi, Davidson, \& Smith 2005). Importantly, these recent studies have shifted the focus on emotions in education beyond neurological, psychobiological and psychological foci to a broader, social constructivist understanding which views emotions as historically and socially constructed as well as deeply shaped by our relations with others.

Schools are particularly important sites for citizen formation as they have long played a key role in establishing rules, norms and behaviours in order to create citizens capable of functioning in particular ways (McLeod 2012, Staeheli 2010, Marston \& Mitchell 2004, Wood 2015b). A growing focus on emotional education has seen the launch of emotional literacy programmes in many countries with the aim of teaching students the skills of respectful social interaction, safe and healthy behaviours, enhanced self-esteem and ethical responsibility to their peers and community members (Boler, 1999, Gagen, 2015, Greenberg et al. 2003). These programmes exemplify initiatives which aim to cultivate democracy through the promotion of certain emotions, of which empathy is the most popular (Thrift 2004, Boler 1999). As Boler (1999) states, 'across the political and disciplinary spectrum, 
conservatives and liberals alike advocate for variations of empathy as a solution to society's "ills"' (p.156). Empathy emerges as a vital emotion for students to develop in order to appreciate how society's ills impact on other people's lives.

Studying empathy or care, similar to other emotions, however, is a complex endeavour (Sheppard, Katz, \& Grosland 2015). Emotions are difficult to see, interpret and define. Moreover, a successful emotional performance can be artificially produced in order to serve a purpose or fit a specific context (Hochschild, 2012; Lindquist, 2004). Emotions can stem from 'transitory responses' to an external event (such as anger, indignation, fear, joy) or from deeper 'underlying affects' (including loyalty to family, friends or places; or fear of others) which contribute to deep affective attachments (Jasper 1998). Both forms of emotion shape politics, identities and citizenship responses as these are forged in and through social relations that rest upon deep feelings of commitment to people and places (Massey 2004). As emotions have moved more toward the centre of public life in recent years (Bondi 2005), in what Thrift (2004) calls an ever increasing intensity of affect, it is more important than ever to consider how they shape the political action of both young people and adults. In particular, we need greater understandings of the 'sociality of emotion' (Ahmed 2014, p. 8) in which emotions are understood to be located not just inside or outside people, but circulate between people, within social contexts, serving as a form of cultural politics or world making. A key challenge that this paper addresses therefore is to examine the significance of affect in youth citizenship action in the context of citizenship education programmes in schools and to consider how such socio-emotional and spatial contexts shape citizen identities and actions.

The complex nature of emotional research meant that we needed to clarify the theoretical approach underpinning our study. We found Zembylas' (2007) three categorises of 
approaches to the study of emotions a useful analytical tool to both understand and interpret how emotions form and circulate within socio-spatial contexts. The first and arguably most dominant traditional approach to the study of emotions in education are psychodynamic approaches which are derived from psychological understandings of emotion. Emotion in this sense is largely understood as an internal feeling that relates to the reactions of individual subjects in response to external stimuli (Zembylas 2007). The second approach views emotion as a sociocultural experience. Also known as a social constructivist approach, understandings of emotions in this view are dependent on the context in which they are expressed and this will differ between cultures and contexts (Zemblyas 2007).

Zembylas defines a third approach as an interactionist position which views emotion as neither simply psychological nor social, but suggests emotions are 'crucial to the processes in which the psychological and the social are produced' (p. 63). This approach takes a closer look at sociocultural contexts and considers how emotions are formed at the intersection of human interaction. As Wetherell states, emotion and affect are part of relational practice '... affect is distributed. It is an in-between, relational phenomenon' (2015, p.158). She explains the need to integrate the psychological with the sociological: '.. we cannot split between semi-conscious, automaton-like, reactive body and the reflective, discursive, interpreting, meaning-making, communicating social actor. Equally we cannot isolate and reify affect' (p. 160). Using this tri-fold framework, we explore how the emotions of care and empathy are constituted in the context of Social Studies classrooms and how these contexts mediate expressions and experiences of social action.

\section{Methodology}


Five schools were purposively selected for the study (Berg 2007) based on the experience and expertise of five teachers in these schools who were identified as leaders in this area and committed to undertaking social action with their students. A convergent parallel mixed method approach was taken in order to provide a comprehensive analysis of the research problem (Creswell 2014). This included a survey of Senior Social Studies teachers $(n=145)$ alongside an in-depth case study approach with teachers and students in the five selected schools. Qualitative data collection included individual and focus group interviews with the five teachers involved in the project, cycles of action research as well as classroom observations of students planning and undertaking social action. The social actions take on average five weeks with students generally forming groups to select and inquire into a social justice issue, and to plan and undertake action(s). The focus of the formal assessment is on students' conceptual understandings and the clarity of their individual reflections upon the strengths and weaknesses of their approach and the impact of their actions, not directly on their emotional engagement. Self-selected students from all five schools took part in focus group discussions after they had completed their social action requirements.

This chapter draws primarily on data from the student focus group interviews and to a lesser extent on teacher interviews. The focus groups consisted of five to nine students each $(n=52)$, providing an opportunity for students to reflect on and evaluate the experience collectively with others from the class (Berg 2007). These data were analysed to identify key themes and patterns that emerged within and between the five case study schools (Creswell 2014).

\section{Creating the conditions for 'caring' classrooms}

As noted earlier, the role that emotions play in the classroom is rarely the central focus of scholarship. Initially, the significance of emotion in taking social action went unseen (Sheppard, Katz, \& Grosland 2015) in setting up our research. Our classroom observations 
and discussions with teachers alerted us to this crucial link between emotional engagement, agency and action in the social action process. Teachers were very clear at the outset that one of their first goals in the programme was to select social issues that would engender an emotional connection for their students if the social action was to be authentic and meaningful. Empathy was the most desired emotion, in keeping with Boler's (1999) claim that this is the most popular emotion to cultivate in democratic education. As Mel stated: '[I need to get my] students to identify or empathize with injustice, therefore become engaged in the context'. Ann described how she spent hours on YouTube before introducing a social issue to the class 'trying to find the clip that I know will hit them in the heart'. Olivia stated: ... you just don't go “aw, I'm gonna have a social action just now". It's like a whole thing, the emotion that there's an injustice or something that needs working on. What will I do about it? What will we do about it? How will we do it? What should we do? (Initial Interview, 6 March, 2015)

These quotes illustrate the integral connection between caring about an issue and emotional engagement and social action that teachers made in their teaching. Teachers saw their attempts to create a 'caring' atmosphere in their classrooms as part of wider goals they held of 'creating an equitable society' (Olivia) and concerns about social justice (Mel). They saw the key avenue to this was by encouraging their students to 'step into other people's shoes' (Janine) and by 'helping young people feel connected, understand themselves, and [learn to] empathise with others' (Mel). These values underpinned their commitment to setting the conditions in their classrooms for meaningful social action with their students, as well as their own identities as social activists.

In order to support this emotional connection, teachers used a number of strategies to introduce social issues that they felt would be compelling. For example, they chose topics with high levels of affective content, showed video clips and documentaries that evoked 
empathy, and highlighted websites profiling children and young people who had made a difference. One teacher, for instance, showed a documentary about poverty in New Zealand and the poor quality of housing for some families. Another examined the plight of refugees fleeing the Middle East to Europe by profiling personal blogs of refugees. Another showed videos of young people who were working against poverty to 'ra-ra' them up a bit' (Rachel). A key goal of these strategies was to create empathy for the people involved and the social issue focused on, resulting in a sense of agency to be able to undertake appropriate social action.

Through these practices, teachers demonstrated what Hochschild (2012) refers to as 'emotional labour', or the management of visible signs of emotion to create an atmosphere or an attribute which has exchange value. Their actions were committed to nurturing a 'caring' classroom. One teacher, Rachel, illustrated this by describing how she modelled emotions she wanted from the students - in this case indignation and outrage:

I often I get angry about [social issues]. And I'll see something and just go 'grrr!' in the front of the class and I'm 'this so annoys me!' [My aim is to let them] see your emotion and then it's alright for them.

Lindquist (2004) suggested that staging empathy is one way to meet the goal of deeper forms of affective engagement from students. In Rachel's case, her modelling of emotions was designed to evoke students' greater emotional connection with the social issue studied. These strategies alert us to the socially constituted nature of emotions such as empathy, and how teachers fostered undeclared emotional 'rules' which served to delineate a zone within which certain emotions were permitted while others were not (Zembylas 2005). In the next section, we examine how students responded to these strategies to consider how such conditions were perceived and understood by students. 


\section{'We did it because it was quite personal': Students who cared}

The majority of students we observed and interviewed across the five schools demonstrated high levels of emotional engagement with their social action focus. For many, a connection or attachment to a social issue was felt emotionally and many voiced a visceral response to their chosen social issue; especially younger students whom we interviewed (aged 15 and 16). For example, in the following group discussion, three 14 year-old female students describe how a sense of empathy sparked a desire to take action:

When we saw the living conditions that people, that some people are living in damp homes... it is just really horrible and I just couldn't imagine living in that sort of place... it was really horrible. I just wanted to help them...

I think the more we learned about [child poverty in New Zealand] the more we felt how much we take things for granted. We learned that what we have is quite a lot you know, yet, like some kids don't really have anything...

Yeah...I really wanted to help. I really want to contribute like to bettering our society and stuff.

Others talked about how 'amazed' they were that an issue hadn't 'been noticed' by the public or how 'shocked' or 'moved' they were by events which seemed unfair or unjust. These responses were both 'transitory emotions' (Jasper 1998) as well as indicative of deeper 'underlying effects' (Jasper, 1998) which motivated their interest and empathetic responses. Young people described such citizens that these assessments conveyed to be as caring, empathetic and active: involved, walking the talk in order 'to make a difference', and importantly, underpinning this was a sense of compassion, as Josh (16 years) described:

[They want us to be] empathetic. Not just know knowing how other people in less fortunate situations feel, but actually feeling it. Like moving you to wanna do something. Like not just being sympathetic and understanding, 'oh yeah, they're suffering', but actually going 'that's terrible, we need to do something'.

Another described this type of citizen as a 'good Samaritan' (Luke 16 years), drawing on a Biblical reference to explain someone who possessed the agency to go out of his/her way to help those in need. 
When it came to selecting their social issue, students were mostly motivated by issues which had a direct relevance to their lives and were situated in the 'micro-politics' of their local communities (Harris \& Wyn 2009). Older students (17-18 years) in one focus group who had completed a social action assessment the previous year reflected that they 'formed a better connection to [the local social issue] rather than [the national-level issue] we did this year there's not that same level of connection'. The significance of young people's experiences of places, communities and local issues in shaping their citizenship actions and dispositions is well established (Harris \& Wyn 2009, Weller 2007, Marsh, O'Toole, \& Jones 2007, Wood 2015a, Harris, Wyn, \& Younes 2010). Local experiences and knowledge also significantly influence young people's interest in social issues and the extent to which they are informed about current issues (Holden, Joldoshalieva, \& Shamatov 2008). For example, having refugee students in the school was a reason some students chose to focus on this issue as 'we thought it was quite important' (Angela, 16 years). Others similarly chose issues such as child poverty as 'many students in our school go without food and lunch and... [we knew about that]' (Jess and Nadine, 14 years).

There were also examples of deeply personal choices of social issues to undertake social action on. Two boys (Jackson and Dylan, 14 years) in one school had a burning issue which affected their families. Jackson's mother, who was Dylan's aunty (both boys happened to be in the same class), had died in the public hospital a year previously. It had become apparent that over-crowding and understaffing had contributed considerably in the death of Jackson's mother and this had been confirmed by a story run by a local television station. The boys decided to write to the local hospital to ask for a formal apology and to address improvements in their systems of patient care. Their close connection to this event was obvious: 
Jackson: My social issue was the way patients were being treated in the hospital. We did it because it was quite personal. [It was about which] happened in the past...

Dylan: The reason why I did it was because it was personal to me as well and I believe that the company that we're arguing with [the hospital] didn't give it too much action [sic].

Their social action was underpinned by a sense of injustice as well as personal tragedy as Dylan outlines. These examples illustrate how young people's 'embeddedness in their local world shapes their thinking about politics and their political and social action' (Harris \& Wyn 2009, p.329). These examples illustrate the integral link between emotion and a continuum of responses from altruism and good neighbourliness through to a sense of agency and more transformative 'activist' sensibilities seeking social justice. Not all students, however, experienced such empathetic responses. In the following section we examine students who didn't 'care'- or at least not as much as the ones described above.

\section{'We weren't very passionate...'? Students who didn't care (as much)}

In every school a small group of students undertaking the social action assessments did not engage deeply with the social issues and the resulting social action process. In some cases, these students were in their last year at school, and had basically 'checked out' already, and were not attending classes or completing school work. None of these largely absent or disengaged students self-selected into our focus groups. Others, however, participated through the social action process, but expressed some reluctance or frustration about this process - often as a result of not being very 'passionate' about the selected social issue. For example, in one class, Kimberly, a 17 year old, described how her group of five students 'wasn't very passionate about anything in the local community' which their teacher had insisted had to be the scale of focus. She described how she would have preferred a more political national-scale issue that was significant to more people. Two younger students described how they didn't really 'care' about their issue, but 'it grew on us I guess and we 
cared more about it' (Jess and Nadine, 14 years). Andrea (16 years), reported that she did care about the issue but felt 'outside her comfort zone' when it came to taking social action and which she did 'feel good' once the action was completed, she would not take the subject the following year.

The degree of freedom within which social action was undertaken had a significant impact on young people's responses. Where there was less choice and freedom, students felt restricted and frustrated. For example, in one class where the teacher had pre-selected the social issue, Ben (17 years) felt it was 'kind of imposed on us' and as a result said, 'I don't feel as emotionally charged about it'. Another group of students (aged 16-17 years) considered that the fact the social action was assessed 'kind of dumbed it down a bit, because [...] it's not so much like you are personally involved, it's sort of like you've got ulterior motives to doing it'. Ben's comment highlights the potential for some forms of coercion to potentially exist in citizenship classrooms, all in the name of creating 'good' citizens (see Wood 2015b, for further on this). Teachers were aware of the potential to be criticised for 'social engineering' and most put in place some strategies to make sure students had some freedom throughout the process by selecting their own social issues and/or forms of social action. One teacher, Mel, went as far as saying 'I will never impose my choice of social issue on them - I am willing for them to fail the assessment before I'd do that'.

One frustration voiced by students in all focus groups was how they had to find ways to manage the disengagement of other students from their group. Generally students completed their action in groups of between two and six, enabling them to spread the workload. Anjali (16 years) summed up the frustration of many when she described it as 'kind of like carrying a dead weight': 
It was quite annoying...some people were really unreliable. We had this plan that we had six actions that were to be done it was like video, emailing, posters, presenting at assembly; four of the actions didn't get done.

This necessitated students themselves 'managing' their peers in order to complete the social action and the assessment, including 'giving them a job that they had to do. And we were constantly checking up on them and making sure they were doing that job' (Tania, 16 years). Josh described how he employed a strategy of asking his group members for their opinions 'because there was no way they were going to offer their opinion without being prompted. So, we constantly asked them...kind of forced them [laughs] to do stuff'. In order to cope with students who were absent or disengaged, Hayley (16 years) said:

We gave them a job that wasn't so important, that if they didn't do it the whole thing wouldn't go down, but they felt like they were still part of the group. And then if they didn't do it, we could still have done it before the end of the thing. So it worked out well and they were still part of it.

These discussions illustrate how students themselves had become part of the governing processes of the classroom, undertaking a fair amount of 'emotional labour' in their strategies to manage their peers' lack of engagement. This also illustrates the impact of a small group of students' emotional disengagement rippling out beyond the private feelings of individuals to shape the responses of their peers. These peers responded with a series of tactics which matched the hidden 'rules' of these classrooms context in a way that connects the psychological to the sociological with almost 'seamless feedbacks' (Wetherell 2015, p. 152).

\section{Discussion and concluding thoughts}

Care is a complex concept and there are multiple ways we can interpret what is happening in classrooms where care is required as part of a formal assessment regime. Our analysis has highlighted that care was an essential part of citizenship action. As Bartos noted, 'care is an 
action, a practice, a goal and a strategy' (2012 p. 160) and can be seen in how children and young people work to maintain, preserve and repair their worlds. Our research confirms the strategic importance of empathy and caring about a social issue if young people are to experience meaningful engagement in their acts of citizenship. Young people's sense of agency and engagement was significantly enhanced when faced with issues with which they had some level of personal experience, interest and understanding, a point made by Freire (1973) many years earlier. Connecting with young people's own experiences increased the sense of care and commitment and also reduced the potential for emotional engineering. In contrast, the students who were disengaged or lacked passion about an issue did not have that sense of emotional connection - either through their own or the teachers' choices, and their disengagement also impacted negatively on others.

Our research also illustrated that geographies of emotion were constituted within the fabric and social settings of classrooms and communities. As Simonson (2005, p. 8), (drawing on Lefebvre's (1991) understanding of the temporality of everyday life) reflects, 'emotions and affections, private life and its symbols cannot submit to cumulative and linear processes'. Instead, the process of taking social action was dynamic, unpredictable and subject to multiple contingencies relating to people and situations. An analysis through Zembylas' (2007) theoretical framework confirms the dynamic and multiple layers of emotion in the citizenship classroom, and helps to explain the psychological, sociocultural and interactionist nature of emotions in this context. Each of these theoretical analyses of emotion added a layer of depth to our understandings of how emotion interacted with the active citizenship process.

The study found that an initial encounter with social issues triggered a psychodynamic or psychological reaction, such as a sense of care, empathy, or indignation and or outrage. These 
responses were visceral, affective and often closely linked to agency and the desire to take action. Osler and Starkey (2005) suggest that first and foremost, citizenship is a feeling and that the status and practice of citizenship follows after this. Teachers worked to create such moments in order to quicken emotional responses as they knew this was requisite for engagement in the social issue, but also to sustain interest and agency to see the social action through. Younger students from this study in particular, were 'moved' by issues, and in particular, ones which seemed have an emotional connection with their lives - through places and people they knew.

It was also apparent that certain emotions and dispositions were promoted through the sociocultural norms and sociocultural practices of these social studies classrooms. The 'rules of the game' in these classrooms, as required by the formal national assessment, stressed that social action was an unequivocal 'good' to be pursued and at all costs. Moreover, the 'correct' or desirable emotions to demonstrate were passion, empathy and engagement, whilst cynicism and disengagement were to be avoided. Such unspoken but present notions of the 'correct' type of emotion were facilitated by unequal power relations in the classroom which serve to reinforce a certain emotional expression or habitus between teachers and students (Reay 2015, Zembylas 2005). A sociocultural analysis also revealed that intergenerational social interactions between young people and teachers affirmed and mediated certain types of emotion and action.

Finally it was apparent that emotions were not 'in' individuals or 'in' the classroom context, but interacted together to create the conditions which enabled and constrained certain emotional responses (Ahmed 2014). In this interactionist (Zembylas 2007) approach, student group interactions operated in different but often parallel ways to how teachers set up the 
classroom and illustrated the circularity of emotion. Our study exemplified how emotion can be seen as the product of social interactions that mimic wider patterns of power and control in society and in this case, the social action process had displaced the locus of responsibility management for young people's emotions from the teachers and on to some students who had assumed (or were given) leadership in their social action groups. Whilst teachers still assumed most of the control over the assessment and process, student leaders within their groups exhibited a degree of emotional labour to find ways to manage their peers. This illustrates the fluidity and pervasiveness of emotions of care (or not caring) when implementing active citizenship education policy which centred on relational connections between teachers and students and then, in turn, students and their peers - all of which were created, governed and mediated by the norms and expectations of this socio-spatial context (Zembylas, 2005; 2007).

Analysing this context through Zembylas (2007) three different approaches reveals that different theoretical approaches shape our understandings of how emotions operate in the classroom. While a psychodynamic approach gave insights into teachers' and students' personal feelings, socio-cultural and interactionist approaches enabled us to see the relational and spatial aspects of emotions, and how these were constituted mutually and collectively between young people and adults. Moreover, the spatial context - which is this case was primarily within the context of schooling sites - shaped the nature of these interactions, serving to both constrain and enable certain forms of emotional response and citizen action. The 'politics of affect' (Thrift, 2004) therefore must be necessarily understood through a socio-spatial analysis that teases out the spatiality and sociality of emotion (Ahmed, 2004). 
The findings of our research present some dilemmas for those involved in the context of citizenship education. While young people need to be emotionally engaged, this engagement cannot be 'forced' if their acts of citizenship are to be meaningful. The findings also suggest that amidst the busyness of school settings, time and freedom needs to be given to allow students opportunities to explore issues which they can connect and emotionally engage with. However, when time-frames are tight, which is especially likely in the context of formally assessed social action for high stakes qualifications, more linear type of social action process may be produced which inevitably result in some students' disengagement. The extreme of this could promote a type of social action that was functional and utilitarian, underpinned by highly 'managed' emotions, superficially producing the 'right' type of attitudes and care. This type of approach is unlikely to result in students adopting long-term social engagement and deeper understandings of citizenship through into their adult lives (Boler, 1999). In contrast, there is potential for an active citizenship experience to be a reflexive and inquiring process, driven by student-interest and informed by deepening knowledge about social issues and social justice and the understanding that young, caring citizens themselves can play a role in shaping society. Acknowledging how young people 'care' in citizenship contexts therefore is a vital yet complex part of the process of learning to become an active citizen. 


\section{References}

Ahmed, S (2014). The cultural politics of emotions (2 ed.). Edinburgh: Edinburgh University Press.

Archer, E., \& Openshaw, R. (1992). Citizenship and identity as 'official goals' in social studies. In R. Openshaw (Ed.), New Zealand Social Studies: Past, Present and Future (pp. 19-33). Palmerston North: Dunmore Press.

Bandura, A. 2006. Adolescent development from an agentic perspective. In F. Pajares \& T. Urdan (Eds). Self efficacy beliefs of adolescents, 307-337. Greenwich, Connecticut: Information Age Processing.

Bartos, A. E. (2012). Children caring for their worlds: The politics of care and childhood. Political Geography, 31(3), 157-166.

Berg, B. L. (2007). Qualitative research methods for the social sciences (6th ed.). Boston: Pearson Education Ltd.

Birdwell, J., Birnie, R., \& Mehan, R. (2013). The state of the service nation: Youth social action in the UK. Retrieved from London:

Black, R. (2015). Between policy and a hard pedagogical place: the emotional geographies of teaching for citizenship in low socio-economic schools. Pedagogy, Culture \& Society, 23(3), 369-388. doi:10.1080/14681366.2014.994664

Boler, M. (1999). Feeling power: Emotion and education. NY: Routledge.

Bondi, L., Davidson, J., \& Smith, M. (2005). Introduction. In J. Davidson, L. Bondi, \& M. Smith (Eds.), Emotional Geographies (pp. 1-16). Aldershot/Burlington: Ashgate.

Bondi, L. (2005). Making connections and thinking through emotions: Between geography and psychotherapy. Transactions of the Institute of British Geographers, 30(4), 433448.

Brooks, R., \& Holford, J. A. (2009). Citizenship, learning and education: Themes and issues. Citizenship studies, 13(2), 85-103.

Brown, G., \& Pickerill, J. (2009). Space for emotion in the spaces of activism. Emotion, Space and Society, 2(1), 24-35.

Creswell, J. (2014). Research design: Qualitative, quantitave and mixed methods approaches. LA: Sage.

Davies, I., Hampden Thompson, G., Tsouroufli, M., Sundram, V., Lord, P., Jeffes, J., \& Bramley, G. (2012). Creating citizenship communities. Journal of Social Science Education, 11(3), 107-118.

Farahmandpour, H. (2011). Beyond 40 hours: Meaningful community service and High School student volunteerism in Ontario. University of Toronto, Ontario Institute for Studies in Education.

Freire, P. (1973). Pedagogy of the oppressed. London: Penguin Books.

Gagen, E. A. (2015). Governing emotions: citizenship, neuroscience and the education of youth. Transactions of the Institute of British Geographers, 40(1), 140-152. doi:10.1111/tran.12048

Greenberg, M. T., Weissberg, R. P., O'Brien, M. U., Zins, J. E., Fredericks, L., Resnik, H., \& Elias, M. J. (2003). Enhancing school-based prevention and youth development through coordinated social, emotional, and academic learning. American Psychologist, 58(6-7), 466-474. doi:http://dx.doi.org/10.1037/0003-066X.58.6-7.466

Harris, A., \& Wyn, J. (2009). Young people's politics and the micro-territories of the local. Australian Journal of Political Science, 44(2), 327-344.

Harris, A., Wyn, J., \& Younes, S. (2010). Beyond apathetic or activist youth: 'Ordinary' young people and contemporary forms of participation. Young, 18(1), 9-32.

Hochschild, A. R. (2012). The managed heart: Commercialization of human feelings. Berkeley: Univeristy of California Press. 
Holden, C., Joldoshalieva, R., \& Shamatov, D. (2008). 'I would like to say that things must just get better': Young citizens from England, Kyrgystan and South Africa speak out. Citizenship Teaching and Learning, 4(2), 6-17.

Jasper, J. (1998). The emotions of protest: Affective and reactive emotions in and around social movements. Sociological Forum, 13(3), 397-424.

Jerome, L. (2012). Service learning and active citizenship in England. Education, Citizenship and Social Justice, 7(1), 59-70.

Kennelly, J., \& Dillabough, J.-A. (2008). Young people mobilizing the language of citizenship: Struggles for classification and new meaning in an uncertain world. British Journal of Sociology of Education, 29(5), 493-508.

Kennelly, J., \& Llewellyn, K. R. (2011). Educating for active compliance: discursive constructions in citizenship education. Citizenship Studies, 15(6-7), 897-914. doi:10.1080/13621025.2011.600103

Kenway, J., \& Youdell, D. (2011). The emotional geographies of education: Beginning a conversation. Emotion, Space and Society, 4(3), 131-136.

Lindquist, J. (2004). Class affects, classroom affectations: Working through the paradoxes of strategic empathy. College English, 67(2), 187-209.

Marsh, D., O'Toole, T., \& Jones, S. (2007). Young people and politics in the UK: Apathy or alienation? Basingstoke: Palgrave MacMillan.

Marston, S. A., \& Mitchell, K. (2004). Citizens and the state: Citizenship formations in space and time. In C. Barnett \& M. Low (Eds.), Spaces of democracy: Geographical perspectives on citizenship, participation and representation (pp. 93-112). London: Sage.

Massey, D. (2004). Geographies of responsibility. Geografiska Annaler, 86B(1), 5-18.

McLeod, J. (2012). Vulnerability and the neo-liberal youth citizen: A view from Australia. Comparative Education, 48(1), 11-26.

Nairn, K., \& Higgins, J. (2011). The emotional geographies of neoliberal school reforms: Spaces of refuge and containment. Emotion, Space and Society, 4(3), 180-186. doi:http://dx.doi.org/10.1016/j.emospa.2010.10.001

Nelson, J., \& Kerr, D. (2006). Active citizenship in INCA countries: Definitions, policies, practices, and outcomes. London: NFER/QCA Retrieved from http://www.inca.org.uk/pdf/Active_Citizenship_Report.pdf.

NZQA. (2013). Social studies subject resources. Retrieved from http://www.nzqa.govt.nz/qualifications-standards/qualifications/ncea/subjects/socialstudies/levels/

Osler, A., \& Starkey, H. (2005). Changing citizenship: Democracy and inclusion in education. Maidenhead: Open University Press.

Pykett, J., Saward, M., \& Schaefer, A. (2010). Framing the good citizen. The British Journal of Politics and International Relations, 12, 523-538.

Reay, D. (2015). Habitus and the psychosocial: Bourdieu with feeling. Cambridge Journal of Education. doi:10.1080/0305764X.2014.990420

Ross, A. (2012). Editorial: Education for active citizenship: Practices, policies and promises. International Journal of Progressive Education, 8(3), 7-14. Retrieved from http://inased.org/v8n3/ijpev8n3.pdf

Schulz, W., Ainley, J., Fraillon, J., Kerr, D., \& Losito, B. (2010). ICCS 2009 International Report: Civic knowledge, attitudes, and engagement among lower-secondary students in 38 countries. Retrieved from Amsterdam:

Sheppard, M., Katz, D., \& Grosland, T. (2015). Conceptualizing emotions in social studies education. Theory \& Research in Social Education, 43(2), 147-178. doi:10.1080/00933104.2015.1034391 
Simonsen, K. (2005). Bodies, Sensations, Space and Time: The Contribution from Henri Lefebvre. Geografiska Annaler: Series B, Human Geography, 87(1), 1-14. doi:10.1111/j.0435-3684.2005.00174.x

Staeheli, L. A. (2011). Political geography: Where's citizenship? Progress in Human Geography, 35(3), 393-400. doi:10.1177/0309132510370671

Thrift, N. (2004). Intensities of feeling: Towards a spatial politics of affect. Geografiska Annaler, 86 B(1), 57-78.

Weller, S. (2007). Teenagers' citizenship: Experiences and education. Oxon: Routledge.

Wetherell, M. (2015). Trends in the Turn to Affect: A Social Psychological Critique. Body \& Society, 21(2), 139-166. doi:10.1177/1357034x14539020

Wood, B. E. (2013). Young people's emotional geographies of citizenship participation: Spatial and relational insights. Emotion, Space and Society, 9(2013), 50-58. doi:10.1016/j.emospa.2013.02.004

Wood, B. E., \& Black, R. (2014). Performing citizenship Down Under: Educating the active citizen. Journal of Social Science Education: Special Issue: Civic activism, engagement and education: Issues and trends, 13(4, Winter 2014), 56-65. doi:10.2390/jsse-v13-i4-1413

Wood, B. E. (2015a). Excluded citizens? Participatory research with young people from a 'failing' school community. Children's Geographies, 1-15. doi:10.1080/14733285.2015.1043515

Wood, B. E. (2015b). Freedom or coercion? Citizenship education policies and the politics of affect. In P. Kraftl \& M. Blazek (Eds.), Children's Emotions in Policy and Practice: Mapping and Making Spaces of Childhood (pp. 259-273). UK: Palgrave MacMillan.

Zembylas, M. (2005). Discursive practices, genealogies, and emotional rules: A poststructuralist view on emotion and identity in teaching. Teaching and Teacher Education, 21(8), 935-948. doi:http://dx.doi.org/10.1016/j.tate.2005.06.005

Zembylas, M. (2007). Theory and methodology in researching emotions in education. International Journal of Research \& Method in Education, 30(1), 57-72. doi:10.1080/17437270701207785

Zembylas, M., Charalambous, C., \& Charalambous, P. (2014). The schooling of emotion and memory: Analyzing emotional styles in the context of a teacher's pedagogical practices. Teaching and Teacher Education, 44(0), 69-80. doi:http://dx.doi.org/10.1016/j.tate.2014.08.001

Zembylas, M., Charalambous, C., Charalambous, P., \& Kendeou, P. (2011). Promoting peaceful coexistence in conflict-ridden Cyprus: Teachers' difficulties and emotions towards a new policy initiative. Teaching and Teacher Education, 27(2), 332-341. doi:http://dx.doi.org/10.1016/j.tate.2010.08.015

Acknoweldgements: This work was supported by funding from the Teaching and Learning Research Initiative (2015-2016), a New Zealand government funded initiative. We are grateful for advice and comments from the Editors and reviewers. 